\title{
Estimation of the Impact of Monetary Policy on Economic Growth: The Case of Cote d'Ivoire in Line with SVAR Methodology
}

\author{
Drama Bédi Guy Hervé \\ Correspondence: Drama Bédi Guy Hervé, Département de Sciences Economiques et de Gestion, Université Peleforo \\ Gon Coulibaly, BP 1328 Korhogo, République de Côte d'Ivoire.
}

Received: March 19, 2017

doi:10.11114/aef.v4i4.2493

\author{
Accepted: May 11, $2017 \quad$ Available online: June 15, 2017 \\ URL: https://doi.org/10.11114/aef.v4i4.2493
}

\begin{abstract}
This paper examines and foresees the impacts of monetary policy on economic growth by studying the case of Cote d'Ivoire through the SVAR model. More specifically, the second target is to analyze which policy is reliable for the explanation of real activities fluctuation in Cote d'Ivoire. Thus, we will use eight structural variable SVAR tools by using monthly time data series running from 1990:1 to 2014:12. This SVAR model is also carried out to generate impulse response function that raises the impact of economic policy shocks on growth in Cote d'Ivoire. In addition, from the estimated SVAR equation, we passed through the estimated structural imposition of restrictions and we generated the forecast error variance decomposition analyses that help us make prediction. Our empirical results demonstrate that innovations in monetary aggregate impact in real activities and prices although very low. This implies that monetary policy shocks are not the main determinant of business cycle movements in Cote d'Ivoire. Second, the empirical analysis also shows that the real interest rate and money aggregate significantly respond to variations in the industrial production index while other variables respond insignificantly. This means that the industrial sector in Cote d'Ivoire is constrained by the higher credit cost in their production process. Finally, since global oil price shock captured real activities and impacted negatively output growth, we recommend a gradual diversification of the domestic economy and optimal fiscal policy that could be reliable because it plays a dominant role.
\end{abstract}

Keywords: output growth, monetary policy, SAR model, Cote d'Ivoire

JEL Code: E3, E5,C22, F32

\section{Introduction}

At its creation in January 1994, West African Economic and Monetary Union (WAEMU) gathered seven countries in sub-Saharan Africa, namely Benin, Burkina Faso, Côte d'Ivoire, Mali, Niger, Senegal and Togo. An eighth country, Guinea Bissau joined the Union in May 1997. These member states are working for the promotion of the enlargement and revival of the economic activities. In the Union convention, it is stated that WAEMU focuses on the goal of ensuring "the convergence of the economic performance and policies among member states through the procedure of multilateral surveillance institution" (Article 4 of the Treaty of The WAEMU, 11 January 1994). Monetary policy is one of the economic policy instruments used today and generally devoted to a central bank. This is the case of the Central Bank of West African States (CBWAS) for the WAEMU zone. The objective of the CBWAS is to guarantee the currency stability. Without prejudice to this objective, the CBWAS shall support the general economic policies elaborated in the Member States of the Monetary Union. The theoretical argument behind this definition can be summed up in two proposals, which refer to current monetary policy concerns: this is to determine the priority objectives of monetary policy and how on the other hand, these objectives can be reached by the Central bank. The next demonstration is how to translate quantitatively the objective of price stability. Here, there are two opposing views. The first thesis is based on the possibility to reduce the inflation rate up to zero.

The second thesis advocates the stabilization of inflation at a level deemed to be tolerable by the monetary authorities. It raises the debate between monetary policy and discretionary monetary policy. For some economists, monetary policy must be satisfied with the application of a passive or non-activist monetary rule (Friedman, 1967, Kydland and Prescott, 1977). This argument leads to admit that through the assumption of temporal incoherence, a discretionary monetary policy is incompatible with the maintenance of price stability. On the other hand, since the "blind" automatic application of rules often leads to a high variability of production, many economists argue in favor of a monetary policy that combines 
the gains of temporal coherence with the advantages of flexibility (Barro and Gordon, 1983, Rogoff, 1985, Taylor, 1998). Such policy is defined as an active monetary rule, which allows systematic reaction of monetary authorities to the production and inflation gaps, while preserving the accounting of the long-term economic policy objectives. So, how to put such a rule credibly (Artus, Penot and Pollin, 1999). Here, Independence of the central bank is sufficient to internalize the inflationary bias of discretionary policy (Mac callum, 1997). It finds its true expression when the monetary authorities set themselves as guardians of price stability. In this context it seems appropriate to deal with the debate that will focus on those who are in favor of a monetary policy focusing on the setting of intermediate targets and on those who are in favor of a monetary policy oriented towards the pursuit of fixed quantitative targets. The choice of some authors was then the quantitative inflation target (Svensson, 1997-1998). Under these conditions, the central bank indicates in advance the rate of inflation it targets and therefore, acts on the money market rate. The fixed quantitative target has two types of advantages: the monetary authorities' credibility in monetary policy and the increased independence of the central bank.

Côte d'Ivoire, an important country of WAEMU, aims at achieving the status of an emerging country by the year 2020 . The Review of the National Development Plan 2012-2015 showed that the actions carried out produced effects in line with the objectives. The prove is that Côte d'Ivoire has undergone an important growth $(9.4 \%$ on average between 2012 and 2014), in a context of a better peace and security, as well as good governance. People have been gaining benefits from renewed dynamism through redistribution and reparation of inequalities in different sectors. In this context of rapid growth, what is the contribution of monetary policy? If we take into account the former studies, we notice that there is no study traces the impacts of monetary policy shocks on domestic economy using a structural vector autoregressive framework for Cote d'Ivoire context. This study aims at estimating the effects of monetary policy on output growth in Cote d'Ivoire using structural vector auto-regression. This background analysis leads us to two main objectives for this work. Our first target will be to estimate the impacts of monetary policy on real variables in Cote d'Ivoire using structural vector autoregressive perspective. The second will permit us to check which instrument, among policies, plays an important role in explaining fluctuation of economic activities in Cote d'Ivoire. The last part of our work is divided as follows: the summary of the Central Bank of West African States policy instruments and target is highlighted in section 2. The model specification, the methodology applied and the data sources are depicted in section 3 . The interpretation and discussion of the econometrics results is viewed in section 4. Then the last section is a concluding part that explains the policy and concludes the discussion.

\section{Summary of the Central Bank of West African States Policy Instruments and Target}

The Central Bank of West Africa States (CBWAS) has a long history of monetary policy in a monetary union, spanning 50 years. This experience is rich in lessons learned as evidenced by the record of its action. A favourable assessment of the common monetary policy led the CBWAS to preserve the monetary stability of the Union. The member states benefit from price stability that many other African countries can envy. The effectiveness of the common monetary policy over the last two decades has been based on gradual reform of the monetary policy instruments, which first consolidated the policy instruments (1989) and then Interest rates, liberalized and positive in real terms, reform the CBWAS's intervention on the interbank market $(1993,1996)$, put in place a system of minimum reserves and renounce the Central Bank's Treasures. The last step was the reform of the CBWAS statutes, which came into force in 2010, to guarantee its independence from governments, thus increasing its credibility and thereby controlling inflation. Through its monetary policy, the CBWAS must naturally maintain the achievement of monetary stability, since this is the main objective assigned by its statutes. But the Central Bank cannot lose interest in the economic growth of the Union. Following Article 8 of its new statutes, "the main objective of the Central Bank's monetary policy is to ensure price stability. The inflation target is defined by the Monetary Policy Committee. Without prejudice to this objective, the Central Bank shall support the economic policies of the West African Economic and Monetary Union (WAEMU) with a view to healthy and sustainable growth ".

More specifically, the aim is to maintain the euro / CFA exchange rate at 655.96 and to stabilize average consumer price inflation around 3\% in line with the convergence criteria of the zone (Couharde et al, 2013; BCEAO, 2016). To achieve these goals, the CBWAS uses four main policy rates including its minimum rate for bids at liquidity auctions, the standing lending facility rate, WAEMU average interbank rate and Average T-bill Rates. Since September 2013, the key refinancing rate remained unchanged at $2.5 \%$, which shows that the CBWAS practices an accommodative monetary policy. Indeed, both, credit to the economy and credit to government are experienced robust growth of about $14 \%$ and $24 \%$ each year (IMF, 2015). Concerning its effect on inflation, it is emphasized that monetary policy has a weak impact on inflation because of the lack of developed and integrated financial markets in the zone. Nevertheless, Inflation is expected to remain low and stable. This is due to two factors: the first one is the improvement of the good supply of food to the market and the decreasing of fuel prices in almost all the countries of the zone (CBWAS, 2016). These two factors combined could explain the good economic performance that Cote d'Ivoire recorded during the period from 2012 to 2016. In fact, the country experienced GDP growth rates of $8.9 \%$ on average. However, as amply illustrated by the theory of optimal monetary unions, an important difficulty of the common monetary policy lies in the asymmetry of 
the exogenous shocks which periodically affect the countries of the Union. The WAEMU countries are characterized by instability and a dispersion of the growth rates of the member states, which are characterized by heterogeneity of their monetary situation. We fear the fact that the intensity of the shocks suffered by the WAEMU states will be amplified because of the present instability of the world economic situation.

\section{Literature Review and Theoretical Framework}

The impact of monetary policy on the real economy and precisely on growth and prices has long been an important topic in macroeconomic theory. It has also been analyzed by several academicians since 1950. It is also fundamental for central bankers to better understanding the consequences of their actions that determine their final goal and to understand the overall macroeconomic fluctuations. This paper uses real variables to forecast the impacts of monetary policy on economic growth by using auto-regression structural vector $(S V A R)$ with a block exogeneity assumption from Cushman and Zha (1997). The theoretical literature detains a preponderance of works both in developed and developing countries that try to measure the impact of monetary policy on real economy (see for e.g. Cushman and Zha, (1997); Christiano et al., (1999); Bernanke and Mihov, (1998); Khan et al., (2002); Berument, (2007)). It is true that these studies detect puzzling results from their analysis, however it seems to have no ambiguous concerning the impact of monetary policy on output growth and prices in developed economies as discussed by Christiano et al., (2002). There are important literatures viewing the impact of monetary policy on economic variables using econometric methodology like Generalized Method of Moments (GMM), a single-equation Regression among others. Most of the empirical works imposed some restrictions on the relationships between monetary policy and economic variables in order to identify policy shocks. More generally, they use forecast error variance decomposition based on Cholesky identification procedure. The monetary policy variables are ordered before the exchange rate. This can be sen with Sims, (1992); Grilli and Roubini, (1995); Eichenbaum and Evans, (1995). This means that there is no simultaneous reaction between monetary policy variables and exchange rate. The restriction can be acceptable for a large and relatively closed economy because the reaction of monetary policy to foreign shocks would be relatively small (see Cushman and Zha, (1997)). This result mixes with the United States economy. However, in small open economies, fluctuations in monetary policy are quite sensitive to both foreign and domestic reel variables shocks as demonstrated by Kim and Roubini, (2000). We can likewise understand that Cholesky procedure seems to work for large closed economies but not for small open economies as shown by Cushman and Zha, (1997); Sato, et al.; (2009); Gossé and Guillaumin, (2013).

Regarding the case of the advanced countries in economy, such as the United States, Canada and some European countries, there is a strong evidence of the effectiveness of monetary policy influence on output growth like presented by Rafiq and Mallick, (2008); Bernake et al., (2005); Mishkin,(2002); Christiano et al., (1999) and Dario and Edward, (2016). For instance, Cushman and Zha, (1997) use a structural vector auto regression with an exogeneity block to identify the monetary policy shock and examine the impacts of external shocks on the Canadian economy. In the context of OECD countries, similar studies have been conducted (e.g., Lastrapes, (1998); Ludwig and Slok, (2004); Vargas-Silva, (2008)). For middle-income economies, most of empirical research demonstrates that monetary policy shocks have some modest impacts on output growths. The case of seven East Asian economies, namely Indonesia, Korea, Malaysia, Philippines, Singapore, Taiwan and Thailand, has been analyzed by Fung, (2002) and obtained similar outcome. Note that the United States variables were incorporated as exogenous foreign variables in the SVAR model. Furthermore, Sato et al., (2009) took the same econometric framework to check if external shocks generated from the United States economy played an important role in influencing real variable movements in East Asia economies from the period of 1978 to 2007. Similar works have been also performed by Zhang and McAleer, (2009) and Gosse and Guillaumin, (2013). In addition, Mehmet and Yildirim, (2013) did the same research for the six fast growing emerging economies namely Brazil, Russia, India, China, South Africa and Turkey denoted by (BRICS-T). The overall results are quite similar, world output shocks are not a dominant source of fluctuations in those economies. In addition, Mustafa and Cengiz, (2014) have used a structural VAR model with the block exogeneity notion to identify and analyze the impacts of some domestic and external shocks and in particular, the impacts of monetary policy shocks on macroeconomic variables in Turkey. All shocks are found to have significant effects on main economic variables. Positive interest rate shocks appreciate the domestic currency and decrease the inflation whereas positive risk premium shocks cause depreciation and an increase in inflation. Both of these shocks also cause a decrease in the domestic activity. Being an open and internationally integrated economy, Turkey is significantly affected by global shocks. Ganev et al., (2002) explored the impacts of monetary shocks in ten Central and Eastern European (CEE) countries and find no evidence that suggests those changes in interest rates affect output, but find some indication that changes in the exchange rate does. In the same order, Starr, (2005) using a SVAR model with orthogonalized identification finds small evidence of real impacts of monetary policy in five Commonwealth of Independent States (CIS) with the remarkable exception that interest rates have a significant impact on output in Russia. Adebayo et al., (2016) paper provides interesting research in explaining the impacts of monetary policy on real economic activities in South Africa with 
SVAR perspective. Their results show that, in short run money supply is observed to play significant positive effects on output growth.

However, for low income countries like Nigeria, the evidence is weak and full of puzzles. For instance, Balolgun, (2007) used simultaneous equation models to test the hypothesis of monetary policy ineffectiveness in Nigeria and found that, rather than promoting growth; erstwhile domestic monetary policy was the source of stagnation and persistent inflation. Similar evidence was also found for The Gambia, Guinea, Ghana and Sierra Leone using the same models. In so doing, we can't ignore that most studies which explores the monetary policy transmission mechanism by using SVAR analyses of open and closed economies, have detected several empirical anomalies. Specially, price puzzles where the price level increases rather than decreases following interest rate Sims, (1992). There are also liquidity puzzles where the nominal interest rate increases rather than decreases following monetary aggregate shock Leeper and Gordon, (1991). Third, there are exchange rate puzzles where domestic currency depreciates relative to the United States dollar, rather than appreciate, followed by a positive interest rate shock: Sims, (1992); Grilli and Roubini, (1995). Finally, there are forward discount bias puzzles where positive interest differentials on domestic assets are associated with persistent appreciations of the domestic currency Kim and Roubini, (2000 p. 562). Thanabalasingam (2013) in his paper title "Monetary Policy and the Real Economy: A Structural VAR Approach for Sri Lanka" attempts to identify the monetary policy variable that better explains the Sri Lankan monetary policy transmission mechanism. This study also estimates how shocks generated from foreign monetary policy and/or oil price affect domestic real variables. In so doing, we utilize a seven variable structural VAR model by using monthly time series data from Sri Lanka running from January 1978:1 to 2011:12. The overall results show that the interest rate plays a robust role in explaining the transmission mechanism of monetary policy of Sri Lanka; however the important notice is that this finding is opposed with studies that proposed the monetary policy transmission mechanism is conducted by the real exchange rate, not the interest rate (see, for example, Cushman and Zha, 1997; Fung, 2002).

\section{Methodology Applied and Data Source}

\subsection{SVAR Modeling}

Since the early 1980s, VAR models have emerged as powerful multivariate models to analyze economic problems. A vector autoregression (VAR) is a set of $\mathrm{k}$ time series regressions in which the regressors are lagged values of all $\mathrm{k}$ series. All variables in each equation of VAR system are included and also because of the existence of correlation among the disturbances of various equations. Cooly and Leroy, (1985) criticized VAR approach as a theory which eventually led to the development of SVAR model. According to the empirical literature, the structural vector autoregression gives more structural interpretation. As we know, Cote d'Ivoire is a small open economy with middle-income level, we apply SVAR model, similar to that performed by Kim and Roubini, (2000). The general approach in the literature is to apply identification restrictions that are consistent with economic theory and prior empirical research findings (see Buckle et al., (2007), Christiano et al., (2005); Dungey and Fry, (2003); Dungey and Pagan, (2000)). Hence, we define the economy by the following structural form of equation:

$$
A_{0} Y_{t}=A_{1} Y_{t-1}+A_{2} Y_{t-2}+\ldots+A_{p} Y_{t-p}+\varepsilon_{t}
$$

Where $A_{1}$ is a (8X8) invertible matrix of parameters for $i=0,1,2, \ldots, p$ while $\varepsilon_{t}$ is (NX1) multivariate white noise

error process and $Y_{t}$ is (NX1) endogenous vector variables at time t with properties as follow:

$$
E\left(\varepsilon_{t} \varepsilon_{\tau}\right)=\sum t=\tau \text { or } E\left(\varepsilon_{t}\right)=0 \text { otherwise }
$$

The structural vector autoregression (SVAR) framework assumes that the structural innovation $\varepsilon_{t}$ are orthogonal while the variance-covariance matrix is constant and diagonal and the structural disturbances are uncorrelated. Moreover, the contemporaneous matrix $A_{0}$ written in equation (1) is normalized across the main diagonal so that each equation in the SVAR system has a designated dependent variable. So the first stage consists in writing the reduce form bellow:

$$
Y_{t}=A_{0}^{-1} A_{1} Y_{t-1}+A_{0}^{-1} Y_{t-2}+\ldots . A_{0}^{-1} A_{p} Y_{t-p}+A_{0}^{-1} \varepsilon_{t}
$$




$$
Y_{t}=B_{1} Y_{t-1}+B_{2} Y_{t-2}+\ldots .+B_{p} Y_{t-p}+\delta_{t}
$$

Where $B_{i}=A_{0}^{-1} A_{i}, i=0,1,2, \ldots, p$ and $\delta_{t}=A_{0} \varepsilon_{t}$. The reduced VAR is expressed by equation (4) and $\delta_{t}$ is the innovation linking to the reduced form with zero mean and constant variance $\delta_{t} \square N(0, \Omega)$. The VAR described by equation (4) is estimated by ordinary least square (OLS) and the VAR residual are depicted by $\delta_{t}$. Note that the structural innovation displayed by equation (3) is linked to the reduced form. Therefore, equation (5) and (6) can be written:

$$
\begin{aligned}
E\left(\delta_{t} \delta_{t}^{\prime}\right) & =A_{0}^{-1}\left(\varepsilon_{t} \varepsilon_{t}^{\prime}\right) A_{0}^{-1}{ }^{\prime} \\
\Omega & =A_{0}^{-1} \sum\left(A_{0}^{-1}\right)^{\prime}
\end{aligned}
$$

Then the second step consists in identifying the contemporaneous matrix and the variance-covariance matrix which maximizes the likelihood function conditional on the parameter estimates of the obtained VAR (Hamilton (1994). In addition, the error term $\left(\varepsilon_{t}\right)$ is a composite of shocks in $Y_{t}$ Enders, (2004). Hence equation (7) and (8) can be specified bellow.

$$
\begin{gathered}
Y_{t}=(I P I, G D P, R E X, I F R, I R, M S) \\
X_{t}=(G P C, G O P)
\end{gathered}
$$

Where industrial production index (IPI), gross domestic product (GDP), real effective exchange rate (REX), consumer price index proxy as inflation rate (IFR), real interest rate (IR) and money aggregate (MS) are endogenous variables among which we can quote two exogenous variables, namely global price (GP) and World oil price (GOP).

\subsection{The Identification Issues}

In order to set up the identification conditions, the SVAR studies of advanced small open economies are used to help us to get the optimal restrictions to be imposed on the contemporaneous and the lagged structure of the Cote d'Ivoire SVAR model. In this study, we use six endogenous variables SVAR model, namely, industrial production index (IPI), gross domestic product (GDP), real effective exchange rate (REX), consumer price index (IFR), real interest rate (IR) and money aggregate (MS) and two exogenous variables, namely, the global price (GP) and world oil price (GOP). However, the exogenous vector $\left\{X_{t}=G O P, G O P\right\}$ of variables is assumed to be a foreign block. The foreign variables are included to control for exogenous change in the global economic system, they are both incorporated to show the small open economy character of Cote d'Ivoire. The endogenous vector $\left\{Y_{t}=I P I, G D P, R E X, I F R, I R, M S\right\}$ is domestic block and we divide it into two parts. One part is non-policy block with two variables $\{G D P, I F R\}$, and the other part is the policy block variables $\{M S, I R, R E X\}$. As we know, domestic activities are depicted by industrial production index (IPI). In addition, we express all variables in natural log excepted real effective exchange rate and real interest rate. To impose short run restrictions structure on matrices A and $\mathrm{B}$, we necessarily refer to structural VAR in equation (1) labeled above and we use the AB-model developed by Amisano and Gianini, (1997; 2012) as follows: 


$$
A=\left[\begin{array}{cccccccc}
1 & 0 & 0 & 0 & 0 & 0 & 0 & 0 \\
N A & 1 & 0 & 0 & 0 & 0 & 0 & 0 \\
N A & N A & 1 & 0 & 0 & 0 & 0 & 0 \\
N A & N A & N A & 1 & 0 & 0 & 0 & 0 \\
N A & N A & N A & N A & 1 & 0 & 0 & 0 \\
N A & N A & N A & N A & N A & 1 & 0 & 0 \\
N A & N A & N A & N A & N A & N A & 1 & 0 \\
N A & N A & N A & N A & N A & N A & N A & 1
\end{array}\right] \quad B=\left[\begin{array}{cccccccc}
N A & 0 & 0 & 0 & 0 & 0 & 0 & 0 \\
0 & N A & 0 & 0 & 0 & 0 & 0 & 0 \\
0 & 0 & N A & 0 & 0 & 0 & 0 & 0 \\
0 & 0 & 0 & N A & 0 & 0 & 0 & 0 \\
0 & 0 & 0 & 0 & N A & 0 & 0 & 0 \\
0 & 0 & 0 & 0 & 0 & N A & 0 & 0 \\
0 & 0 & 0 & 0 & 0 & 0 & N A & 0 \\
0 & 0 & 0 & 0 & 0 & 0 & 0 & N A
\end{array}\right]
$$

Where A is a triangular matrix with the different one on the main diagonal and B and is a diagonal matrix with "NA" as missing value (uncorrelated).

\subsection{Impulse Response Function}

Impulse response functions (IRFs) for our study helps us to examine the behavior of an error shock to each variable on its own future dynamics as well as on the future dynamics of the other variables Gunasekarage and al., (2004). In another words, The Impulse response function is derived and used to examine the dynamic responses of the variables to various shocks within the SVAR system. If we consider L as lag operator, equation (5) can be specified as follows:

$$
B(L) Y_{t}=\delta_{t}
$$

The effect of any shock given by $\delta_{t}$ dies out at some point of horizon time for the covariance stationary VAR. In this situation, equation (11) can be reparameterized to describe the endogenous variables in $Y_{t}$ as function of present and past values of $\delta_{t}$ where the vector moving average (VMA) representation is written bellow:

$$
B(L) Y_{t}=\delta_{t}+C_{1} \delta_{t-1}+C_{2} \delta_{t-2}=C(L) \delta_{t} \quad \text { with } \quad C(L)=(B(L))^{-1}
$$

As far as we know SVAR framework assumes that the structural innovations $\delta_{t}$ are orthogonal and the structural disturbances are uncorrelated. Therefore, equation (12) admits a moving average representation (MA) label as:

$$
Y_{t}=C^{*}(L) \delta_{t}
$$

Where $C^{*}(L)=C(L) A_{0}^{-1}$ generates the impulse response functions of $Y_{t}$ to the structural shocks to $\delta_{t}$. The effects of monetary policy shocks on other local variables, particularly non policy variables (output and prices) can be captured more precisely by the impulse response function. Then the disturbance $\delta_{t}$ can be interpreted in a meaningful way.

\subsection{Forecast Error Variance Decomposition}

Forecast error variance decomposition (FEVD) is used to detect the causal relations among the variables. It also explains the degree at which a variable is explained by the shocks in all the variables at various forecast time horizons in the system Mishra, (2004). The s-period-ahead forecast error is given as follow:

$$
\hat{Y}_{t+s}-\hat{Y}_{t+s / t}=\delta_{t+s}+C_{1} \delta_{t+s-1}+C_{2} \delta_{t+s-2}+\ldots+C_{s-1} \delta_{t+1}
$$

From the equation above, we can write the mean squared error of the s-period forecast as follows: 


$$
\begin{gathered}
\operatorname{MSE}\left(\hat{Y}_{t+s / t}\right)=\Omega+C_{1} \Omega C_{1}^{\prime}+C_{s-1} \Omega C_{s-1}^{\prime} \\
\operatorname{MSE}\left(\hat{Y}_{t+s / t}\right)=A_{0}^{-1} \sum\left(A_{0}^{-1}\right)^{\prime}+C_{1} A_{0}^{-1} \sum\left(A_{0}^{-1}\right)^{\prime} C_{1}^{\prime}+\ldots+C_{s-1} A_{0}^{-1} \sum A_{0}^{-1} \sum\left(A_{0}^{-1}\right)^{\prime} C_{s-1}^{\prime}
\end{gathered}
$$

Where $\Omega=A_{0}^{-1} \sum\left(A_{0}^{-1}\right)^{\prime}$ and equation (15) denotes the contribution of the orthogonal innovations $\delta_{t}$ to the MSE

of the s-period-ahead forecast of variables in $Y_{t}$.

\subsection{Data Sources}

In this study, we use six endogenous variables SVAR model, namely, industrial production index (IPI), gross domestic product (GDP), real effective exchange rate (REX), consumer price index (IFR), real interest rate (IR) and money aggregate (MS) and two exogenous variables, namely, the world commodity price (GCP) and the oil price (GOP). It's consisting for us to use monthly data covering the period of 1990:1 to 2014:12. We captured the two exogenous variables (world commodity price, oil price) from the International Financial Statistics data base (2015) where other variables derived from the World Development Indicators, published by the World Bank (2015). See table 1 bellow.

\begin{tabular}{|c|c|c|c|}
\hline Variable & Definition & Sources & Abbreviation \\
\hline Foreign Block & & IFS & GOP \\
\hline Global Oil Price & $\begin{array}{l}\text { World Oil Price Index }(\mathrm{log}) \\
\text { Base year } 2005(=100)\end{array}$ & & \\
\hline World Commodity Price & $\begin{array}{l}\text { World Commodity Price Index(log) } \\
\text { Base } 2005(=100)\end{array}$ & IFS & GCP \\
\hline \multicolumn{4}{|l|}{ Domestic(Non-policy) } \\
\hline Output & $\begin{array}{l}\text { Gross Domestic Product } \\
\text { Constant prices in local currency(log) }\end{array}$ & WDI & GDP \\
\hline Price Index & $\begin{array}{l}\text { Consumer Price Index log Base } 2005 \\
(=100)\end{array}$ & WDI & IFR \\
\hline \multicolumn{4}{|l|}{ Domestic(Policy) } \\
\hline Exchange Rate & Real exchange rate & WDI & REX \\
\hline Interest Rate & Real Effective Interest Rate (\%) & IFS & IR \\
\hline Money & Money Supply log & WD & MS \\
\hline Industrial Production & Industrial Production Index (log) & IFS & IPI \\
\hline
\end{tabular}

Table1. Variables included in Cote d'Ivoire SVAR system

Sources: International Financial Statistics/World Development Indicators.

\section{Empirical Results and Interpretations}

To avoid problems of spurious regression, we first start by examining the stationarity properties of the data base. So we perform traditional unit root tests by performing the standard augmented Dickey-Fuller test Dickey, (1979); Fuller, (1979) and Phillips-Perron, (1988) tests. Further to the traditional unit root tests, we also use Ng-Perron (NP) test and the Kwiatkowski, Phillips, Schmidt and Shin (KPSS) test to solve the problems of size distortions inherent to the traditional tests Madalla and Kim, (1998). The outcomes are displayed in table 2 and show that all variables are first difference stationary. However, the PP, KPSS and NP tests give the same results, thus, according to the empirical foundation, we found that all variables follow the I(1) process.

Table 2. Summary of stationary tests

\begin{tabular}{|c|c|c|c|c|c|}
\hline \multirow{2}{*}{ Variables } & \multicolumn{4}{|c|}{ Estimation Techniques } & \multirow{2}{*}{ Remarks } \\
\cline { 2 - 5 } & ADF & PP & KPSS & NP & Difference in model \\
\hline LogGDP & $I(1)$ & $I(1)$ & $I(1)$ & $I(1)$ & Difference in model \\
\hline LogIPI & $I(1)$ & $I(1)$ & $I(1)$ & $I(1)$ & Difference in model \\
\hline LogINFR & $I(1)$ & $I(1)$ & $I(1)$ & $I(1)$ & Difference in model \\
\hline LogMS & $I(1)$ & $I(1)$ & $I(1)$ & $I(1)$ & Difference in model \\
\hline $\boldsymbol{I R}$ & $I(1)$ & $I(1)$ & $I(1)$ & $I(1)$ & Difference in model \\
\hline $\boldsymbol{R E X}$ & $I(1)$ & $I(1)$ & $I(1)$ & $I(1)$ & Difference in model \\
\hline LogGCP & $I(1)$ & $I(1)$ & $I(1)$ & $I(1)$ & Difference in model \\
\hline LogGOP & $I(1)$ & $I(1)$ & $I(1)$ & $I(1)$ & \\
\hline
\end{tabular}


Source: Own computation from data use in the regression

Beyond testing for the unit root, there is a need to find the optimal lag length. In so doing, we use the ordinary least square procedure to estimate the reduced form of VAR. Then, the optimal lag length is selected based on Schwarz's Bayesian information criterion (SBIC), the Akaike information criterion (AIC), and the Hannan-Quin information criterion (HQIC). The results are depicted in table 3.

Table 3. VAR Lag Order Selection Criteria

\begin{tabular}{ccccccc}
\hline \hline Lag & LogL & LR & FPE & AIC & SC & HQ \\
\hline \hline 0 & 2740.374 & NA & $1.10 \mathrm{e}-18$ & -18.65102 & -18.55053 & -18.61077 \\
1 & 6460.953 & 7212.590 & $1.59 \mathrm{e}-29$ & -43.61060 & $-42.70626^{*}$ & $-43.24840^{*}$ \\
2 & 6541.706 & $152.1347^{*}$ & $1.42 \mathrm{e}-29^{*}$ & $-43.72495^{*}$ & -42.01675 & -43.04079 \\
3 & 6566.391 & 45.15889 & $1.86 \mathrm{e}-29$ & -43.45660 & -40.94453 & -42.45048 \\
\hline \hline
\end{tabular}

* indicates lag order selected by the criterion,

LR: sequential modified,

FPE: Final prediction error test statistic (each test at $5 \%$ level)

AIC: Akaike information criterion, SC: Schwarz information criterion,

HQ: Hannan-Quinn information criterion.

Sources: Own computation from data used in the regression.

As for the number of lags in the model, according to the standard information mentioned above, the optimal lag length selected is two. Third, the co-integration test is conducted following Johansen, (1988) and Juselius,(1990) procedure. This test is conducted to verify weather our series are co-integrated or not. The co-integration test is done to confirm if the VAR is stable (table 4 displays the results).

Table 4. Cointegration tests results

\begin{tabular}{lllcccccccc}
\hline $\begin{array}{c}\text { Null } \\
\text { Hypothesis }\end{array}$ & $\begin{array}{c}\text { Alternative } \\
\text { Hypothesis }\end{array}$ & Eigenvalue & $\begin{array}{c}\text { Trace } \\
\text { Statistic }\end{array}$ & $\begin{array}{c}0.05 \\
\text { Critical } \\
\text { Value }\end{array}$ & Prob. ${ }^{\star \star}$ & Max-Eigen & $\begin{array}{c}\text { Trace } \\
\text { Statistic }\end{array}$ & $\begin{array}{c}0.05 \\
\text { Critical } \\
\text { Value }\end{array}$ & \begin{tabular}{c} 
Prob. ${ }^{\star *}$ \\
\hline$r \leq 0$
\end{tabular} \\
& $r=0$ & 0.138337 & 149.6798 & 175.1715 & 0.4785 & 0.138337 & 44.36947 & 175.1715 & 0.4785 \\
$r \leq 1$ & $r=1$ & 0.100517 & 105.3103 & 139.2753 & 0.7953 & 0.100517 & 31.56874 & 139.2753 & 0.7953 \\
$r \leq 2$ & $r=2$ & 0.081698 & 73.74154 & 107.3466 & 0.8864 & 0.081698 & 25.39826 & 107.3466 & 0.8864 \\
$r \leq 3$ & $r=3$ & 0.064305 & 48.34328 & 79.34145 & 0.9334 & 0.064305 & 19.80667 & 79.34145 & 0.9334 \\
$r \leq 4$ & $r=4$ & 0.046442 & 28.53661 & 55.24578 & 0.9566 & 0.046442 & 14.17133 & 55.24578 & 0.9566 \\
$r \leq 5$ & $r=5$ & 0.035241 & 14.36528 & 35.01090 & 0.9583 & 0.035241 & 10.69123 & 35.01090 & 0.9583 \\
$r \leq 6$ & $r=6$ & 0.011685 & 3.674047 & 18.39771 & 0.9851 & 0.011685 & 3.502491 & 18.39771 & 0.9851 \\
$r \leq 7$ & $r=7$ & 0.000576 & 0.171556 & 3.841466 & 0.6787 & 0.000576 & 0.171556 & 3.841466 & 0.6787 \\
\hline
\end{tabular}

Trace test indicates no cointegration at the 0.05 level/ denotes rejection of the hypothesis at the 0.05 level Source: Own computation from data used in the regression.

We fail to reject the null hypothesis that long-term relationship exists between aggregate output and its determinants at 5\% level. Hence, all variables are not co-integrated. Furthermore, to make sure that the residuals observations are serially uncorrelated, the residual correlation test is performed. We detected that the p-values associated are significantly no null, so the residuals are correlated see table. 
Table 5. Variance-covariance matrix

\begin{tabular}{|c|c|c|c|c|c|c|}
\hline \multicolumn{7}{|l|}{ Covariance } \\
\hline Probability & RESID01 & RESIDO2 & RESID03 & RESIDO4 & RESID05 & RESID06 \\
\hline RESID01 & 11.32329 & & & & & \\
\hline \multirow[t]{2}{*}{ RESIDO2 } & 0.749758 & 42.17780 & & & & \\
\hline & 0.5546 & - & & & & \\
\hline \multirow[t]{2}{*}{ RESID03 } & $-9.46 E-05$ & 0.000389 & $6.73 E-07$ & & & \\
\hline & 0.5551 & 0.2074 & - & & & \\
\hline \multirow[t]{2}{*}{ RESID04 } & 0.000170 & 0.000629 & 4.04E-07 & $2.53 E-06$ & & \\
\hline & 0.5836 & 0.2939 & 0.0000 & - & & \\
\hline \multirow[t]{2}{*}{ RESIDO5 } & 0.000191 & 0.000166 & $-8.42 E-08$ & $6.43 E-07$ & $1.99 E-06$ & \\
\hline & 0.4868 & 0.7543 & 0.2093 & 0.0000 & - & \\
\hline \multirow[t]{2}{*}{ RESID06 } & -0.000593 & -0.000454 & 5.99E-07 & $2.40 \mathrm{E}-07$ & 6.77E-08 & $1.60 E-05$ \\
\hline & 0.4475 & 0.7633 & 0.0015 & 0.5156 & 0.8361 & - \\
\hline \multirow[t]{2}{*}{ RESID07 } & 0.001288 & 0.000892 & 3.35E-07 & 1.85E-06 & $3.69 E-06$ & $-1.19 E-07$ \\
\hline & 0.1079 & 0.5650 & 0.0865 & 0.0000 & 0.0000 & 0.9007 \\
\hline \multirow[t]{2}{*}{ RESID08 } & -0.000794 & -0.004220 & $-1.47 E-08$ & $-4.31 E-06$ & $-8.71 E-07$ & $-1.30 E-06$ \\
\hline & 0.4887 & 0.0558 & 0.9581 & 0.0000 & 0.0690 & 0.3402 \\
\hline
\end{tabular}

Sources: Own computation from data used in the regression.

Therefore, we estimate structural VAR model with first difference logarithm, excepted real interest rate and real effective exchange rate. In this way, the long-term identification issue is avoided (table 6).

\subsection{Forecast Error Variance Decomposition}

As mentioned above, the forecast error variance decomposition helps us to examine interactions among economic variables over time horizon. In other words, it analyses the importance of shocks in tracing variations among variables. Thus it will guide us to detect the effect of monetary policy on aggregate output. In so doing, for the easy interpretation of our problem, the monthly quarterly is used. The results are presented in table 7 and 8 bellow.

Table7. Variance decomposition of aggregate output (GDP)

\begin{tabular}{cccccccccc}
\hline Period & S.E. & LogGDP & LNIPI & LogINFR & IR & LogMS & REX & LogGOP & LogGCP \\
\hline 3 & 0.001408 & 97.68802 & 0.000541 & 0.001815 & 0.000163 & 0.002097 & 0.021981 & 2.276492 & 0.008892 \\
6 & 0.001945 & 93.17522 & 0.029914 & 0.034682 & 0.016108 & 0.005540 & 0.023824 & 6.623212 & 0.091498 \\
9 & 0.002351 & 89.08877 & 0.133622 & 0.142301 & 0.093519 & 0.045464 & 0.020759 & 10.12000 & 0.355564 \\
12 & 0.002685 & 85.48789 & 0.319832 & 0.324842 & 0.235969 & 0.154852 & 0.016867 & 12.76755 & 0.692200 \\
\hline
\end{tabular}

Source: Own computation from data used in the regression.

Interestingly, aggregate output shows $97.69 \%$ in explaining the variation of its own shocks while the other variables contributions are insignificant in the first quarter excepted global oil price which captures $2,28 \%$ to the variations of output aggregate. In the second, third and fourth quarter, the aggregate output contributes respectively $93,18 \%, 89,09 \%$ and $85,49 \%$ to its own lagged value (variation) while global oil price captures the external effects by $6,62 \%, 10,12 \%$ and $12,77 \%$ respectively. However, the contributions of other variables remain insignificant for the whole periods. The overall responses to output growth demonstrates that only LogGOP significantly influences the fluctuation of output growth for all quarters while LogIPI, LogINFR, IR, $\log M S, \log G C P$ and REX are insignificant.

Table 8. Industrial production index

\begin{tabular}{cccccccccc}
\hline Period & S.E. & LogGDP & LogIPI & LogINFR & $I R$ & $\operatorname{LogMS}$ & REX & LogGOP & LogGCP \\
\hline 3 & 0.002729 & 10.05598 & 89.25247 & 0.017868 & 0.065174 & 0.057997 & 0.005560 & 0.407321 & 0.137624 \\
6 & 0.003733 & 11.49684 & 86.12835 & 0.011195 & 0.751286 & 0.480956 & 0.089357 & 0.635400 & 0.406614 \\
9 & 0.004444 & 12.65489 & 82.72619 & 0.024537 & 1.961067 & 1.157823 & 0.275859 & 0.637820 & 0.561815 \\
12 & 0.004999 & 13.35299 & 79.40267 & 0.080063 & 3.536706 & 1.960709 & 0.534442 & 0.612664 & 0.619758 \\
\hline
\end{tabular}

Source: Own computation from data used in the regression. 
Regarding table 8, the industrial production index responds simultaneously to its own shocks estimated to $89.25 \%$ fluctuation, while the remaining variables explain about $10.75 \%$. Concerning these $10.75 \%$ variation, the aggregate output explains $10.06 \%$; while the remaining variables do not respond significantly to the industrial production in Cote d'Ivoire after three months. After one quarter, the aggregate output $(\log G D P)$ explains $11.50 \%$ to the $86.13 \%$ explained by industrial production (LogIPI) to its own shocks. Turning to the third and fourth quarter (Q3-Q4), gross domestic product shows respectively $12.65 \%$ and $13.35 \%$ in explaining the fluctuation in growth, however for Industrial production, its own shocks demonstrates respectively $82.73 \%$ and $79.40 \%$. In addition, the real interest rate and money aggregate seem to contribute significantly in explaining the movement of industrial production index growth after the second quarter (third and fourth quarters, respectively). Therefore, the overall analysis shows that industrial production index (LogIPI) responds to its own variation, real interest rate $\log \mathrm{IR}$ and $\log \mathrm{MS}$ responds significantly to the fluctuations of industrial production index covering third and fourth quarter, however $\log \mathrm{GCP}, \log \mathrm{GOP}, \log I \mathrm{NFR}$ and REX responded insignificant during the entire period (Q1-Q4).

\subsection{Impulse Response Function}

We use the response function estimated to explore the effects of innovations in monetary policy variables economic growth and prices through the SVAR system. Our estimated impulse response function covers the periods of 12 months (four quarters) are presented in the panel of figures 1 at $95 \%$ confidence level figure 1 (see appendix). As mentioned above, each figure in the panel explains the response of the non-policy variable on the policy variable.

Our empirical work with a real interest rate as monetary policy instrument shows theoretically consistent outcome for growth, real effective exchange rate and price level. As we know, under monetary contraction and output, money demand and prices are expected to slow down while interest rate and exchange rate will appreciate. Hence, positive interest rate shocks maintain significant output growth over one quarter (Q1), and then gradually shift under the baseline about three quarters. However, the insignificant effect of the interest rate shock on output means that the domestic credit market is inefficient; that's why the production level still low. Furthermore the domestic currency remains stable and statistically significant over twelve months. Moreover, the price level initially confuses to the baseline rise slowly, stay constant within 12 months and significant at the conventional level implies that inflation rate is stable in Cote d'Ivoire and does not capture negatively output. In addition, we observe a positive innovation in the money growth shocks on real output. The estimated impulse response produces a positive money shock on output, significant but the effect is very low. This result implies that the monetary policy doesn't have significant effect on real economy growth in Cote d'Ivoire. Also we find a negative innovation in the global oil price which implies an insignificant impact shock on GDP almost twelve months (Q1-Q4). These results mix with our theoretical expectations assuming that Cote d'Ivoire is a small open economy with fixed exchange rate regime.

\section{Conclusion and Implication of Policy}

The main target of this paper is to investigate on the impact of monetary policy shocks on output growth in Cote d'Ivoire with structural vector auto-regression (SVAR) perspective. In other words, we take an open economy SVAR model to explore the interaction of Cote d'Ivoire's economic activities. We also employed real variables and identified policy instrument that really explain the mechanism of monetary policy transmission. In so doing, the monthly data from 1990:1 to 2014:12 has been used to address the problem. We carry out a SVAR model to generate impulse response function that traces the impact on monetary policy shocks on growth and inflation in Cote d'Ivoire. In addition, from the estimated SVAR equation, we passed through the estimated structural imposition of restrictions and we generated the forecast error variance decomposition analyses that help us to predict. The results from impulse response function depicted by figure 1 (see appendix) demonstrate that monetary aggregate innovations have low impacts on real output linking with the selected policy variables. In the same order, innovations in monetary policy react significantly with real activities and prices but the effect is very low. From these results, we can partially conclude that innovation in monetary aggregate are not the main determinant of Cote d'Ivoire's business cycle movements. Then we confirm that fiscal policy plays more dominant role. The response copes with the traditional Keynesian IS-LM model and the Mundell-Fleming hypothesis. The results from the forecast error variance decomposition depicted in tables 7 and 8 provide reliable information for policy interpretation over the impulse response horizon. The overall analysis shows that industrial production index response to its own shocks, real interest rate and money aggregate respond significantly to the fluctuations of industrial output covering third and fourth quarter. However, price, exchange rate, global price and the oil price were insignificant for the entire periods (Q1-Q4). In addition, the examination of all variables response to real output explains that only global oil price significantly influences the fluctuation in real growth for the entire period (Q1-Q4) while price, real interest rate, monetary aggregate, global commodity price and real exchange rate were insignificant. The influence of real interest rate shocks on industrial production index remains above $3.5 \%$ in the third and fourth quarter (Q3-Q4). This implies that industrial sector in Cote d'Ivoire is constrained by the higher credit cost in their production process. Since global oil price shock captures real activities and impacts negatively GDP growth, we 
recommend that a gradually diversification of the domestic economy and optimal fiscal policy could be rely on for the dominant role it plays.

\section{References}

Adebayo et al., (2016). Monetary Policy and Output Growth Forecasting in a SVAR Perspective. International Journal of Economics and Finance, 8(7). https://doi.org/10.5539/ijef.v8n7p71

Amisano, G., \& Giannini, C. (1997). Model selection in Structural VAR analysis. In Topics in Structural VAR Econometrics. Springer Berlin Heidelberg. https://doi.org/10.1007/978-3-642-60623-6_7

Artus, P., Penot, A., \& Polin, J. P. (1999). Quelle règle monétaire pour Banque Centrale Europenne? Revue d'Economie Politique, 109(3).

Balogun, E. (2007). Monetary policy and economic performance of West African Monetary Zone countries. MPRA Paper N03408.

Bernanke, B. S., \& Blinder, A. S. (1992). The Federal funds rate and the channels of monetary transmission. American Economic Review, 82(4), 901-921.

Bernanke, B. S., \& Mihov, I. (1998). Measuring monetary policy. The Quarterly Journal of Economics, 113(3), 869-902. https://doi.org/10.1162/003355398555775

Bernanke, B., Jean, B., \& Piotr, E. (2005). Measuring the effects of monetary policy: A Factor-Augumented vector autoregressive approach, Quarterly Journal of Economics, (2), 387-422.

Berument, H. (2007). Measuring monetary policy for a small open economy: Turkey, Journal of Macroeconomics, 29, 411-430. https://doi.org/10.1016/j.jmacro.2006.02.001

Buckle, R. A., Kim, K., Kirkham, H., McLellan, N., \& Sharma, J. (2002). A structural VAR model of the New Zealand business cycle(p. 36). Wellington, New Zealand: The Treasury.

Christiano, L., Eichenbaum, M., \& Evans, C. (1996). The effects of monetary policy shocks: evidence from the flow of funds. Review of Economics and Statistics, 78, 16-34. https://doi.org/10.2307/2109845

Christiano, L., Martin, E., \& Charles, E. (1999). Monetary policy shocks: what have we learned and to what end? In Woodford, Michael and John. https://doi.org/10.1016/s1574-0048(99)01005-8

Christiano, L., Martin, E., \& Charles, E. (2002). Nominal rigidities and the dynamic effects of a shock to monetary policy, Federal Reserve Bank of Chicago.

Christiano, L., Martin, E., \& Charles, E. (2005). Nominal Rigidities and the Dynamic Effects of a Shock to Monetary Policy. J.P.E. 113(February), 1-45.

Cooley, T., \& Leroy, S. (1985). A Theoretical Macroeconomics: A Critique. Journal of Monetary Economics, 16, 283-308.

Couharde, C., Coulibaly, I., \& Damette, O. La dynamique d'ajustement des taux de change réels dans la zone franc CFA, Revue économique, 63(3), 545-555. https://doi.org/10.1016/0304-3932(85)90038-8

Cushman, D. O., \& Zha, T. (1997). Identifying monetary policy in a small open economy under flexible exchange Rates. Journal of Monetary Economics, 39(3), 433-448. https://doi.org/10.1016/S0304-3932(97)00029-9

Dario et al., (2016). Monetary Policy, Real Activity, and Credit Spreads: Evidence from Bayesian Proxy SVARs, Finance and Economics Discussion Series 2016-049. Washington: Board of Governors of the Federal Reserve System. https://doi.org/10.17016/feds.2016.049

Dickey, D., \& Fuller, W. (1979). Distribution of the Estimators for Autoregressive Time Series with a Unit Root, Journal of the American Statistical Association, 74, 427-431. https://doi.org/10.1080/01621459.1979.10482531

Dickey, D., \& Fuller, W. (1981). Likelihood Ratio Statistics for Autoregressive Time Series with a Unit Root, Econometrica, 49, 1057-1072. https://doi.org/10.2307/1912517

Dungey, M., \& Fry, R. (2009). The identification of fiscal and monetary policy in a structural VAR. Economic Modelling, 26(6), 1147-1160. https://doi.org/10.1016/j.econmod.2009.05.001

Dungey, M., \& Pagan, A. R. (2000). A Structural VAR Model of the Australian Economy, Economic Record, 76, 321-342. https://doi.org/10.1111/j.1475-4932.2000.tb00030.x

Eichenbaum, M., \& Evans, C. L. (1995). Some empirical evidence on the effects of shocks to monetary policy on exchange rates. Quarterly Journal of Economics, 110(4), 975-1010. https://doi.org/10.2307/2946646

Enders, W. (2004). Applied econometric time series (2nd ed.). Hoboken, NJ: John Wiley \& Sons. 
Fung, B. S. C. (2002). A VAR analysis of the effects of monetary policy in East Asia. BIS Working Papers No 119. Monetary and Economic Department: Bank for International Settlements.

Ganev, G., Molnár, K., Rybiński, K., \& Woźniak, P. (2002). Transmission Mechanism of Monetary Policy in Central and Eastern Europe, CASE ReportsNo. 52.

Gossé, J. B., \& Cyriac, G. (2013). Can External Shocks Explain the Asian Side of Global Imbalances? Lessons from a Structural VAR Model with Block Exogeneity. Review of International Economics, 21(1), 85-102. https://doi.org/10.1111/roie.12022

Grilli, N., \& Roubini, N. (1995). Liquidity models in open economies: Theory and empirical evidence. NBER Working Paper No 5313. Cambridge: National Bureau of Economic Research.

Gunasekarage, G., Pisedtasalasai, A., \& Power, D. M. (2004). Macroeconomic Influence on the Stock Market: Evidence from an Emerging Market in South Asia. Journal of Emerging Market Finance, 3(3), 285-304. https://doi.org/10.1177/097265270400300304

Hamilton, J. D. (1994). Time series analysis (Princeton University Press,Princeton. NJ).

Ivrendi, M., \& Yildirim, Z. (2013). Monetary policy shocks and macroeconomic variables: Evidence from fast growing emerging economies, Economics Discussion Papers 2013-61, Kiel Institute for the World Economy (IfW).

Johansen, (1988). Statistical analysis of cointegration vectors, Journal of Economic Dynamics and Control, 12(2-3), 231-254.

Johansen, S., \& Juselius, K. (1990). Maximum Likelihood Estimation and Inferences on Co-integration with Application to the Demand for Money. Oxford Bull. Econ. Stat., 52, 169-210. https://doi.org/10.1111/j.1468-0084.1990.mp52002003.x

Kahn, M., Shmuel, K., \& Oded, S. (2002). Real and nominal effects of central bank monetary policy, Journal of Monetary Economics, (49) 1493-1519. https://doi.org/10.1016/S0304-3932(02)00179-4

Kim, S., \& Roubini, N. (2000). Exchange rate anomalies in industrial countries: A solution with Structural VAR Approach. Journal of Monetary Economics, 45, 561-586. https://doi.org/10.1016/S0304-3932(00)00010-6

Kydland, F., \& Prescott, E. (1977). Rules rather than discretion: The inconsistency of optimal plans, Journal of Political Economy, 85, 473-490. https://doi.org/10.1086/260580

Lastrapes, (1998). The Dynamic Effects Of Money: Combining Short-Run And Long-Run Identifying Restrictions Using Bayesian Techniques, The Review of Economics and Statistics, 80(4), 588-599.

Leeper, E., \& David, G. (1992). In search of the liquidity effect, Journal of Monetary Economics, 29(3), 341-369. https://doi.org/10.1016/0304-3932(92)90031-V

Ludwig, \& Slok (2004). The Relationship between Stock Prices, House Prices and Consumption in OECD Countries the B.E. Journal of Macroeconomics, 4(1)1, 1-28. https://doi.org/10.2202/1534-5998.1114

Maddala, G. S., \& Kim, I. M. (1998). Unit Roots, Cointegration and Structural Change. Oxford University Press, Oxford.

McCallum, B. T. (1983). On non-uniqueness in rational expectations models: An attempt at perspective. Journal of Monetary Economics, 11, 139-68. 1988. Robustness properties of a rule for monetary policy. Carnegie-Rochester Conference Series on Public Policy 29, 173-203. https://doi.org/10.1016/0167-2231(88)90011-5

Mehmet, I., \& Zekeriya, Y. (2013). Monetary Policy Shocks and Macroeconomic Variables: Evidence from Fast Growing Emerging Economies Discussion Paper No. 2013-61, December 09, 2013

Milton, F. (1967). The Monetary Theory and Policy of Henry Simons, Jour. Law and Econ., Oct., 10, 1-13. https://doi.org/10.1086/466628

Mishkin, F. (2002). The role of output stabilization in the conduct of monetary policy, Working Paper No. 9291. NBER.

Mishra, A., \& Mishra, V. (2010). A VAR model of monetary policy and hypothetical case of inflation targeting in India. Discussion Paper No 15/10. Department of Economics: Monash University. ISSN 1441-5429.

Mustafa, \& Cengiz (2014). Identifcation of Monetary Policy Shocks in Turkey: A Structural VAR Approach. WORKING PAPER NO: 14/23

Perron, P. (1989). The great crash, the oil price shock, and the unit root hypothesis. Econometrica, 57, 1361-1401. https://doi.org/10.2307/1913712

Perron, P. (1997). Further evidence on breaking trend functions in macroeconomic variables. Journal of Econometrics, 
80(2), 355-385. https://doi.org/10.1016/S0304-4076(97)00049-3

Rafiq, \& Mallick (2008). The effect of monetary policy on output in EMU3: A sign restriction approach Journal of Macroeconomics, 30(4), 1756-1791. https://doi.org/10.1016/j.jmacro.2007.12.003

Robert, J. B., \& David, B. G. (1983). Source: The Journal of Political Economy, 91(4), (Aug., 1983). 589-610. Published by: The University.

Rogoff, K. (1985). The Optimal Degree of Commitment to an Intermediate Target. Quarterly Journal of Economics, 100 (1985).1169-1190. https://doi.org/10.2307/1885679

Sato, K., Zhang, Z., \& McAleer, M. (2010). Identifying shocks in regionally integrated East Asian economies with structural VAR and block exogeneity. Mathematics and Computers in Simulation, 81(7), 1353-1364, ISSN 0378-4754. https://doi.org/10.1016/j.matcom.2010.06.009

Sato, T., Hidaka, T., \& Fukuda, M. (2009). Depicting the dynamics of living the life: The trajectory equifinality model. In J. Valsiner, P. Molenaar, N. Chaudhary, \& M. Lyra (Eds.), Dynamic process methodology in the social and developmental sciences. New York: Springer. https://doi.org/10.1007/978-0-387-95922-1_10

Sims, C. A. (1992). Interpreting the macroeconomic time series facts: The effects of monetary policy. European Economic Review, 36, 975-1000. https://doi.org/10.1016/0014-2921(92)90041-T

Starr, M. (2005). Does money matter in the CIS? Effects of monetary policy on output and prices .Journal of Comparative Economics, (33), 441-461. https://doi.org/10.1016/j.jce.2005.05.006

Svensson L. E. O. (1997a). Inflation Forecast Targeting: Implementing and Monitoring Inflation Targets, European Economic Review, 41, 111-1146. https://doi.org/10.1016/S0014-2921(96)00055-4

Svensson L. E. O. (1997b). Optimal Inflation targets, 'conservative central banks, and linear inflation contracts', American Economic Review, 87, 98-114. https://doi.org/10.2139/ssrn.1325

Svensson L. E. O. (1998a). Inflation Targeting as a Monetary Policy Rule, NEBER working paper N0. 6790.

Taylor, J. B. (1998). The Robustness and Efficiency of Monetary Policy Rules as Guidelines for Interest Rate Setting by the European Central Bank, Seminar Papers 649, Stockholm University, Institute for International Economic Studies.

Thanabalasingam (2013). Monetary Policy and the Real Economy: A Structural VAR Approach for Sri Lanka. National Graduate Institute for Policy Studies 7-22-1 Roppongi, Minato-ku,Tokyo, Japan 106-8677/ GRIPS Discussion Paper13-13

Vargas-Silva (2008). Monetary Policy and International Remittances University of Oxford - Harris Manchester College $\begin{array}{llll}\text { Journal of Developing Areas, } & \text { 43(2), }\end{array}$ http://www.financialafrik.com/2017/03/02/uemoa-la-bceao-fait-le-point-de-lannee-2016/\#.WQMhR9LyjIU

Zhang, Michael, McAleer, Kiyotaka, S., \& Zhao,Y. (2009). Identifying Shocks in Regionally Integrated East Asian Economies with Structural VaR and Block Exogeneity, No EI 2009-49, Econometric Institute Research Papers, Erasmus University Rotterdam, Erasmus School of Economics (ESE), Econometric Institute. 


\section{Appendix}

Note 1: Not that we don't display table 6 because space problem but evidence is available upon request.

Response to Cholesky One S.D. Innovations ?2 S.E.

Response of LNGDP to IR

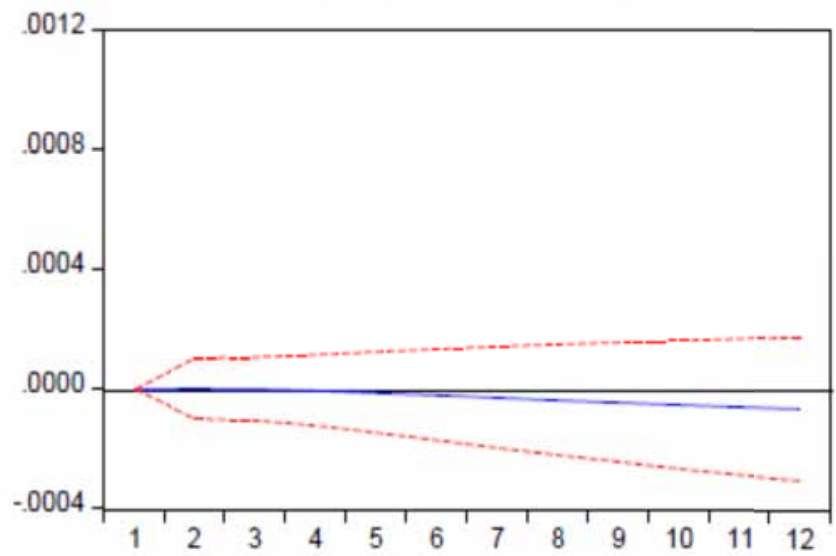

Response of LNGDP to LNMS
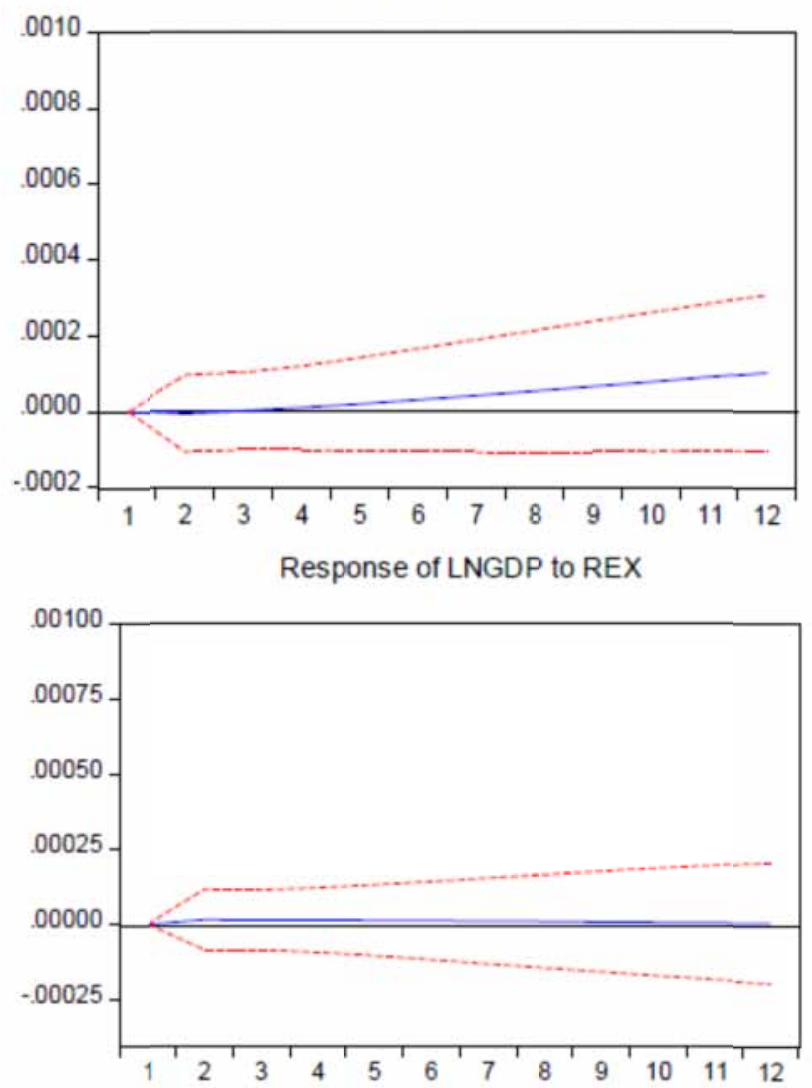

Response of IR to LNGDP

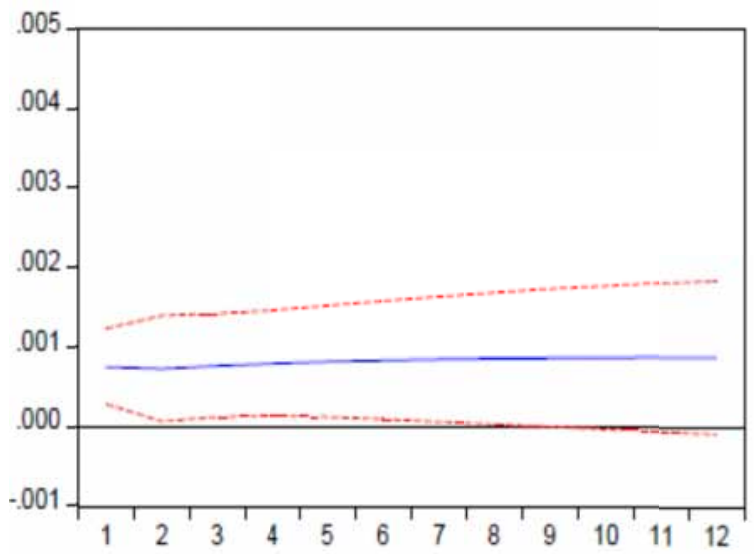

Response of LNMS to LNGDP

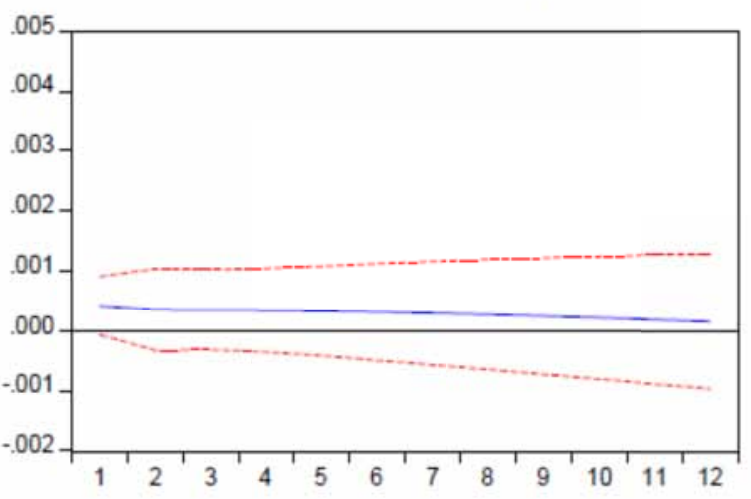

Response of REX to LNGDP

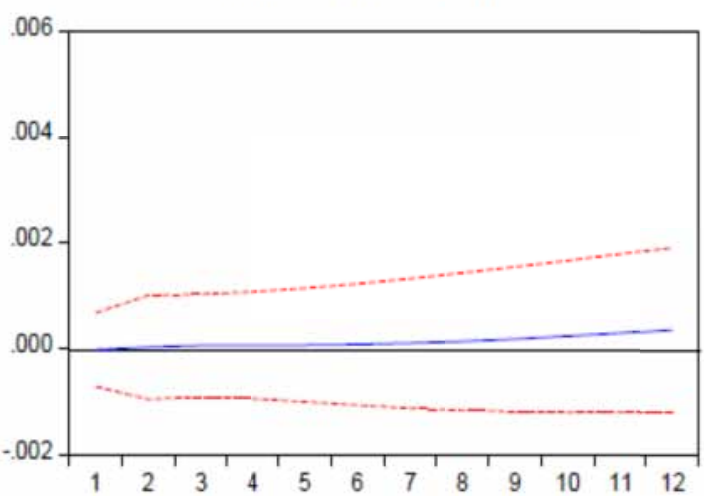




\section{Response of LNGDP to LNINFR}

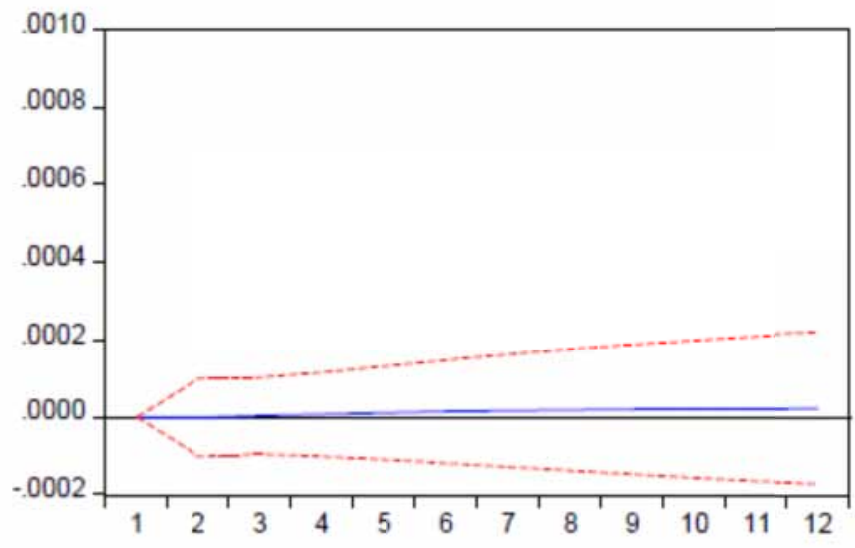

Response of LNGDP to LNIPI

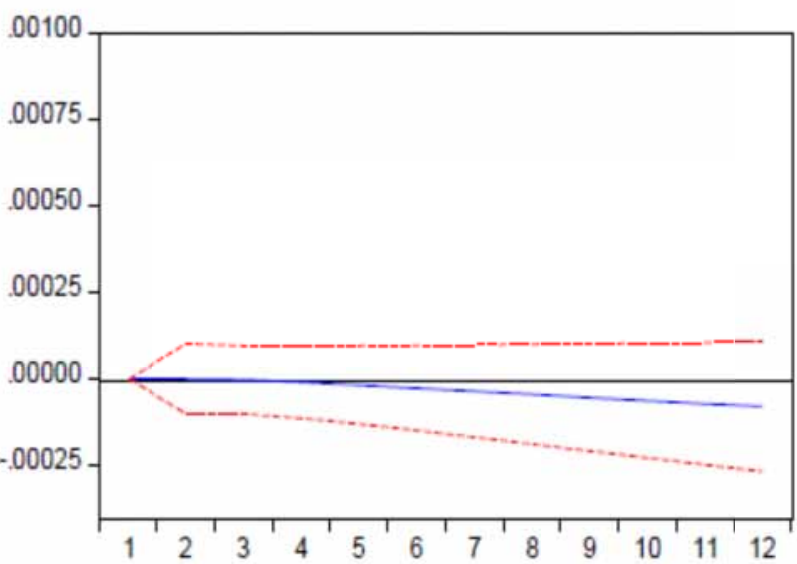

Response of LNGDP to LNGOP

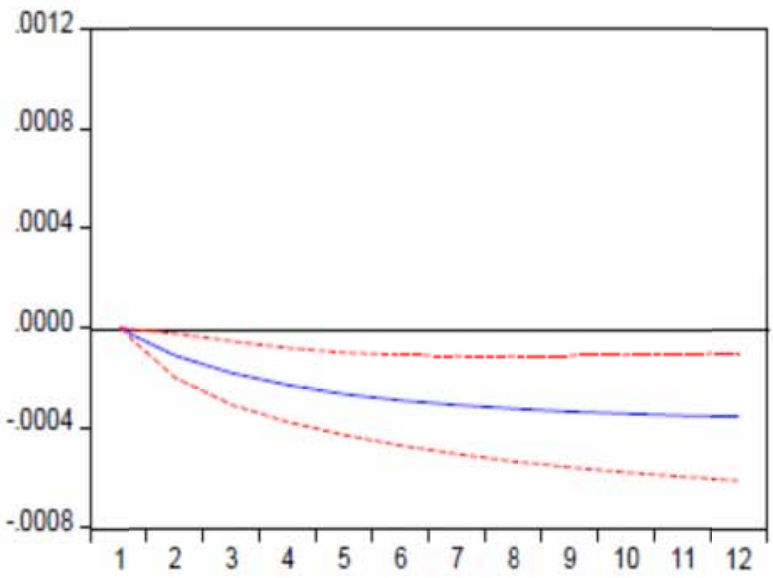

Response of LNINFR to LNGDP

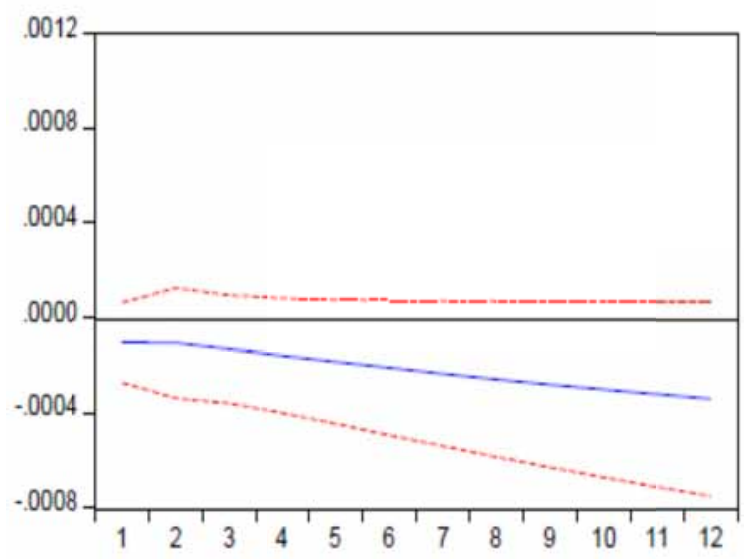

Response of LNIPI to LNGDP

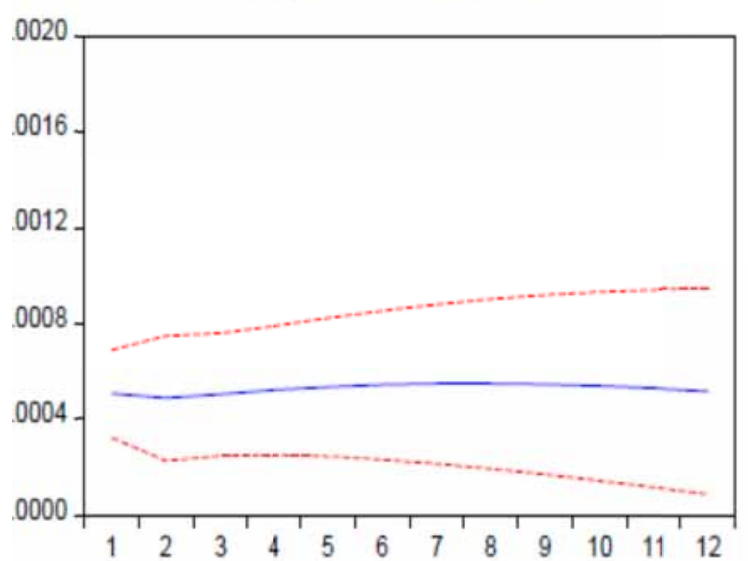

Response of LNGOP to LNGDP

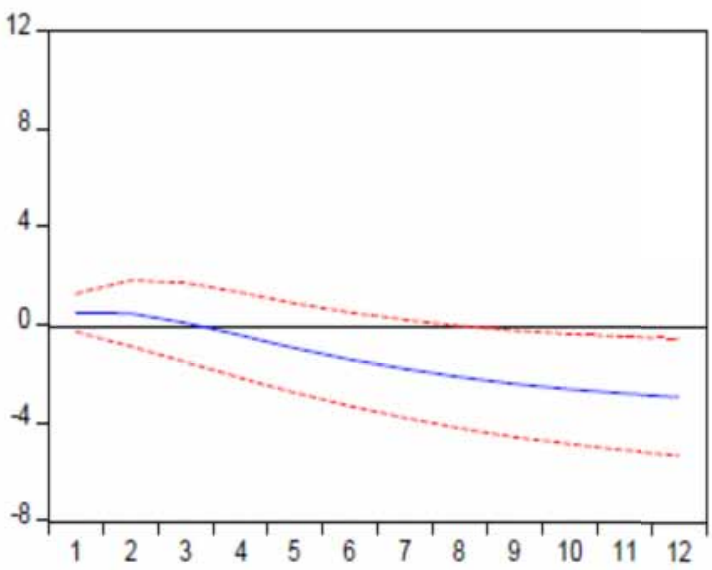


Response of LNGDP to LNGCP

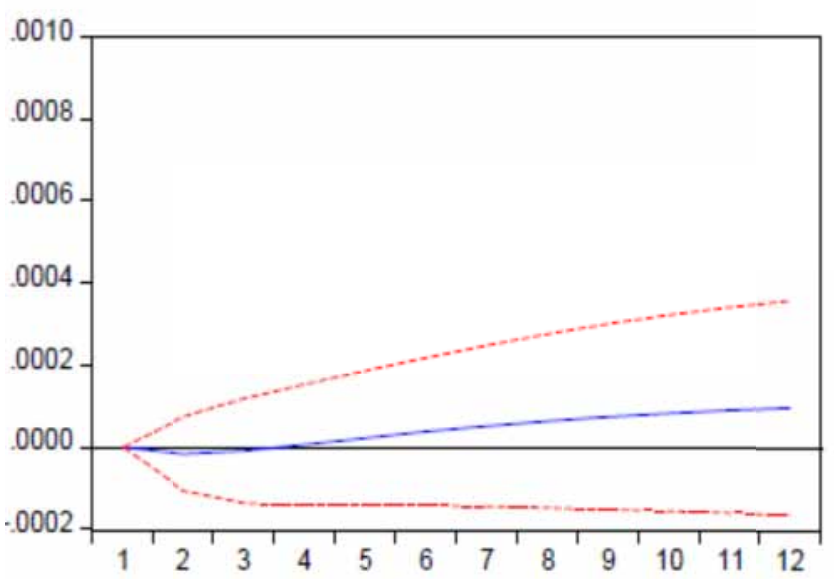

\section{Response of LNGCP to LNGDP}

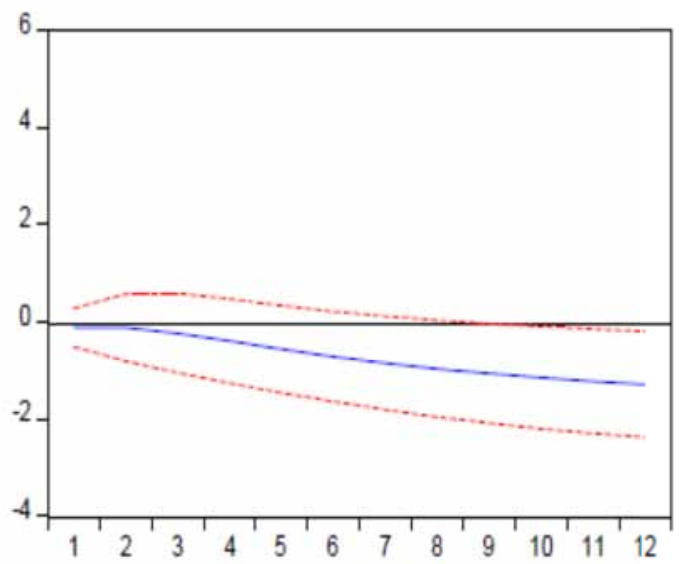

Figure 1. Impulse Response

LNGCP

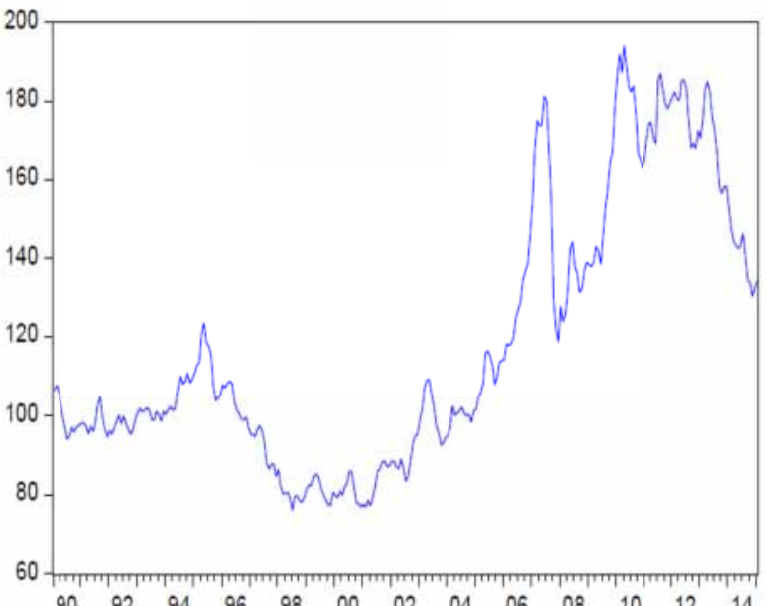

LNGOP

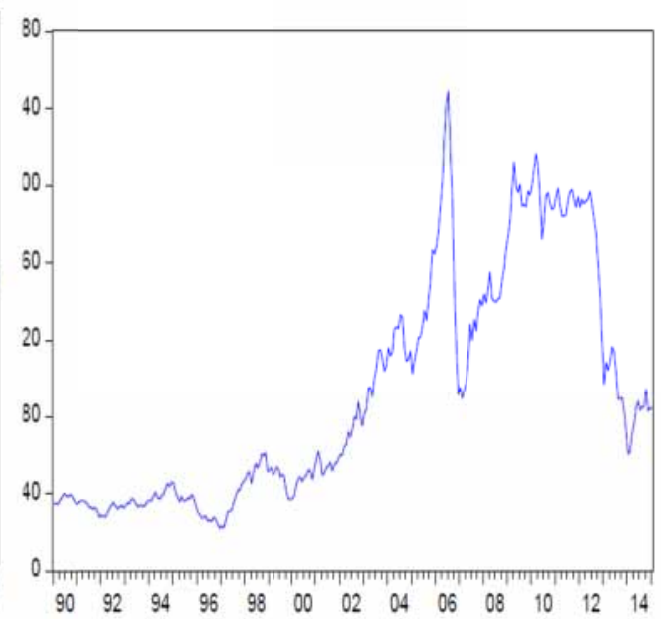


LNGDP

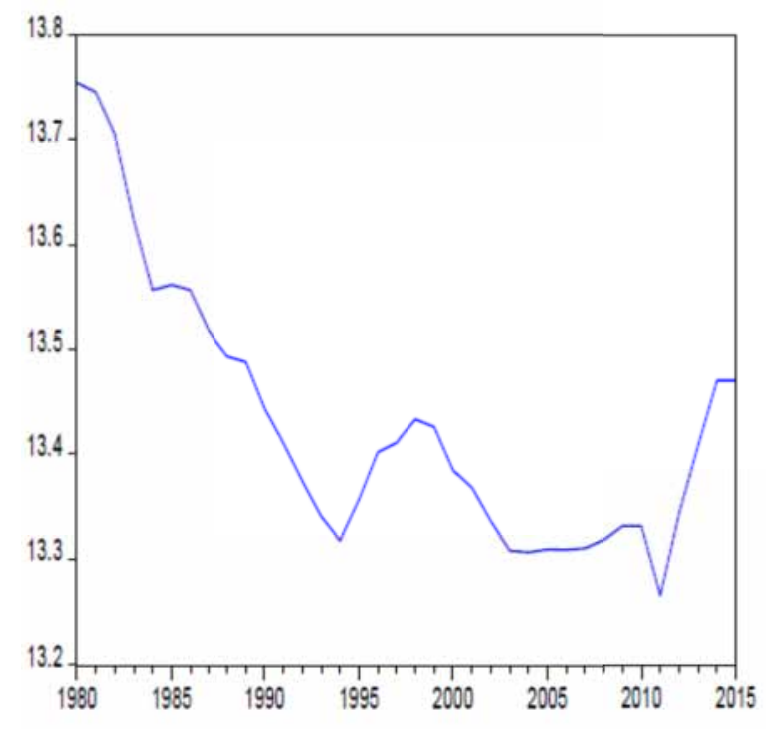

LNIPI

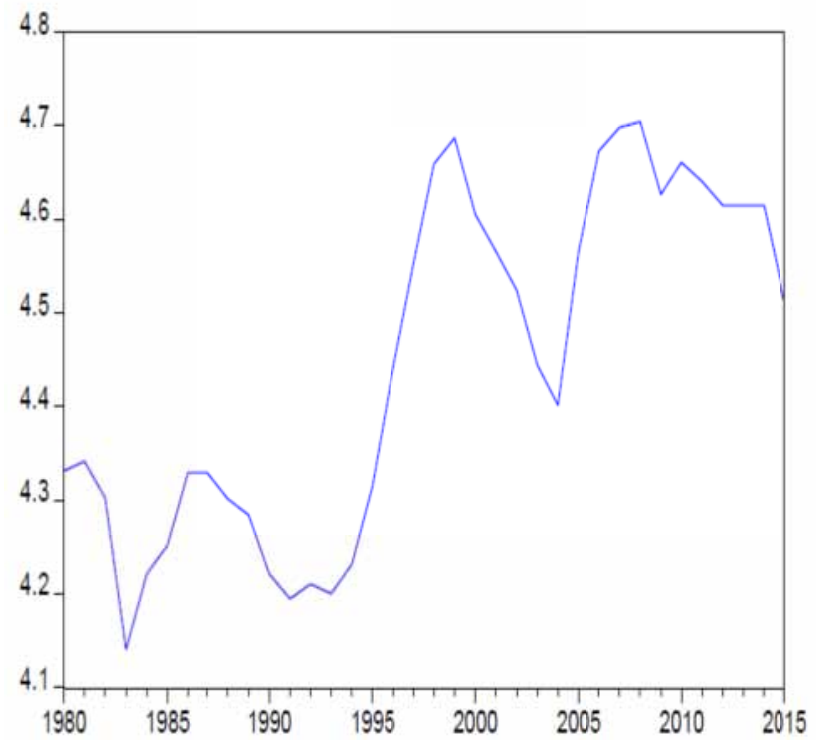

\section{LNINFR}

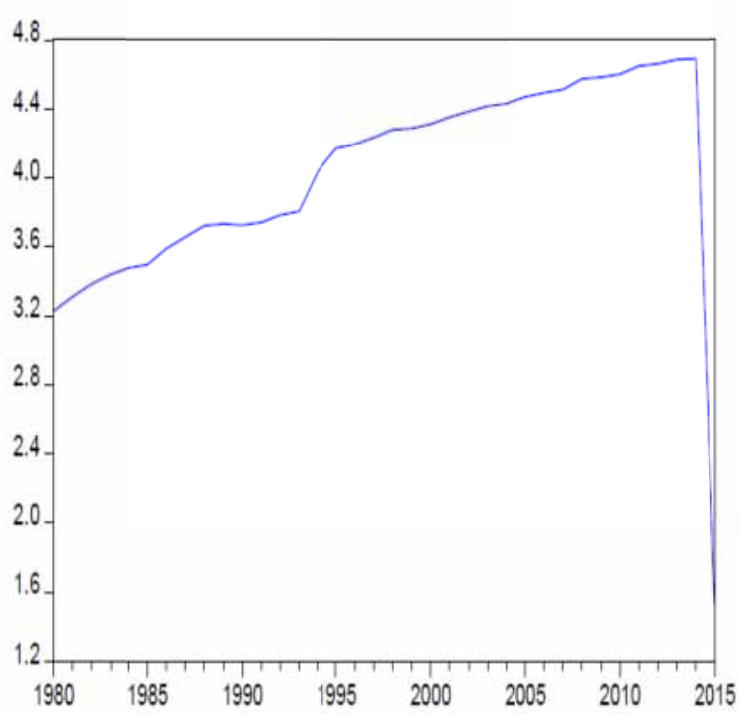

LNMS

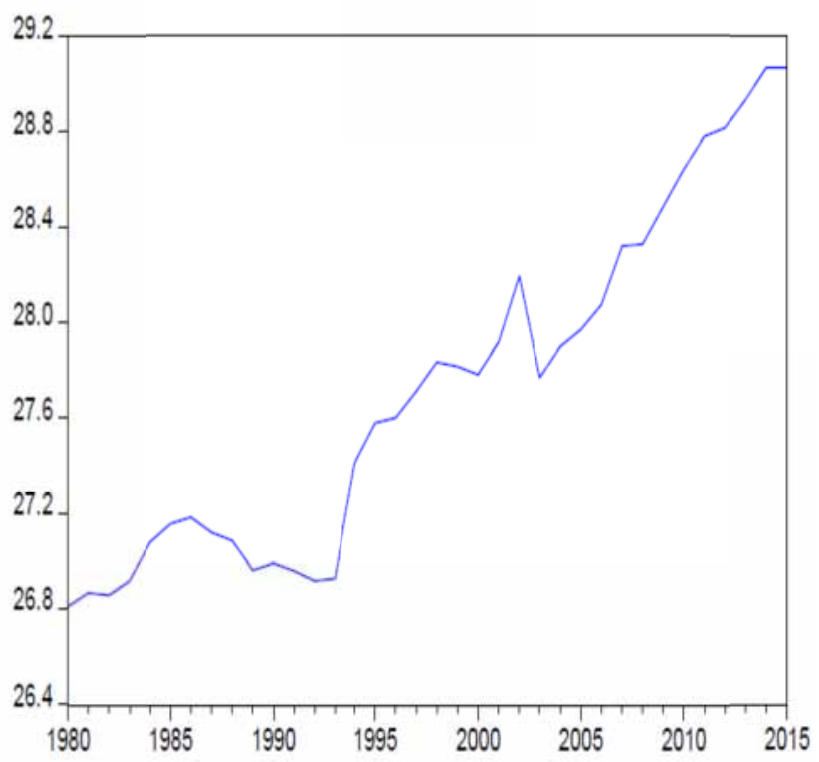


REX

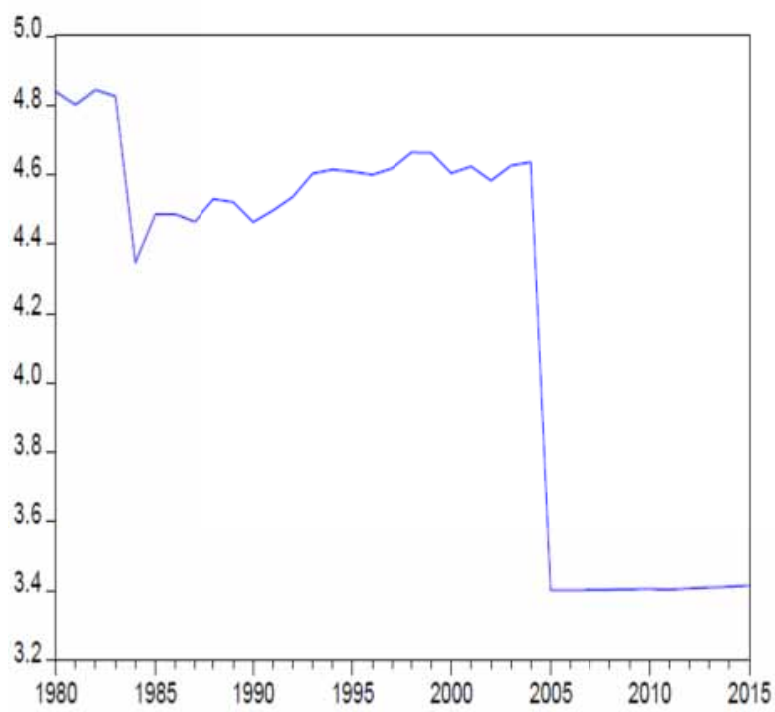

LNGOP

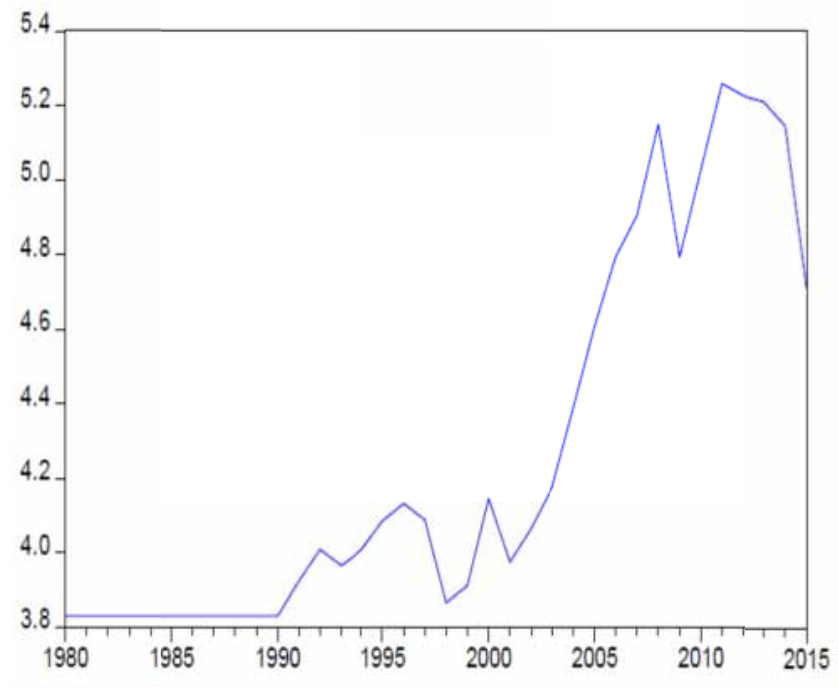

Figure 2. Economic indicators trend

\section{Copyrights}

Copyright for this article is retained by the author(s), with first publication rights granted to the journal.

This is an open-access article distributed under the terms and conditions of the Creative Commons Attribution license which permits unrestricted use, distribution, and reproduction in any medium, provided the original work is properly cited. 